\author{
M. S. VENKATARAMANI \\ B. K. SHRIVASTAVA
}

\title{
THE PRESIDENT AND THE MAHATMA: AMERICA'S RESPONSE TO GANDHI'S FAST, FEBRUARY-MARCH 1943
}

Early in February 1943 Mohandas Gandhi informed the Governor General of India, Lord Linlithgow, that he had decided to undertake a fast for a period of twenty-one days. Gandhi was at that time a prisoner at the Aga Khan palace in the city of Poona, near Bombay. He and his associates had been arrested on 9 August 1942 after the All India Congress Committee had adopted a resolution calling for the withdrawal of British rule over India. Violent protest demonstrations and attacks on government property by angry Indians following the arrest of the leaders was met by ruthless repressive measures. With thousands of nationalists thrown into prison and with the overwhelming coercive authority of the British Indian Government mobilized against them, the leaderless and unarmed Indian adherents and supporters of the Congress Party were beaten back and cowed down.

The world was at this time in the throes of a bloody war. By the end of 1942 the tide of war had slowly begun to turn against the Axis Powers, but the end was hardly in sight and the outcome was by no means certain. From London, and in even greater measure from Washington, there emanated an unceasing flow of propaganda on the determination of the Allied nations to liberate the victims of Nazi tyranny and ensure to mankind the Four Freedoms promised by the Atlantic Charter. British Prime Minister Winston Churchill and the American President, Franklin D. Roosevelt, were convinced that they were engaged in a task on which depended not merely the survival of their own countries but the very future of civilization. To these masterful men who were then at the very pinnacle of power came the tidings early in February 1943 that Gandhi would fast for a period of three weeks.

In the present article an effort will be made to examine the impact of Gandhi's fast on the Roosevelt Administration and the response of the latter to it. The President's attitude was influenced greatly by his nation's involvement in the war against the Axis and by intimate association with Great Britain. The overriding objective of winning the war and the desire to avoid any action that might be unacceptable to 
the British ally were factors to which a great deal of weight was given by the President and elite groups in the United States. It is appropriate to discuss the American response to the situation created by Gandhi's fast against the background of the evolution of Roosevelt's attitude towards developments in India.

\section{MILITARY CONSIDERATIONS INFLUENCE ROOSEVELT}

Till the outbreak of the Second World War developments in India were only of marginal interest to American leaders. In the State Department a few persons like A.A. Berle, Jr., Assistant Secretary of State, and Wallace Murray, Chief of the Division of Near Eastern Affairs, were of the view that the United States should pay some attention to its own objectives in the South Asian region and cease to regard Indian developments as the exclusive concern of Great Britain. Especially after the fall of France, when Britain desperately stood in need of American assistance, Berle and Murray urged that the United States should call upon the British Government to explore the possibility of bringing India into the partnership of Allied nations on terms equal to those of members of the British Commonwealth. But their suggestion did not find favour with Secretary of State Cordell Hull and Under Secretary Sumner Welles who were convinced that "it would be undesirable to do anything which might upset the Indian apple cart at this critical juncture". When a few months later, Berle and Murray again urged that the President should take up the Indian question with the British Prime Minister, Winston Churchill, they were decisively rebuffed by their superiors. ${ }^{1}$

Even though the United States was still a neutral, President Roosevelt was already deeply committed to a policy of aiding Britain. He was convinced that the United States should support the magnificent efforts of Churchill to mobilize the resources of the entire British Empire and Commonwealth against the Axis Powers. He had no desire to challenge Britain's imperialistic course in India or elsewhere. To the victims of Nazi aggression, however, he sought to convey the sympathy and goodwill in eloquent language. Since his statements were couched in universal terms, they were received very favourably by politically

1 Memorandum by the Assistant Secretary of State (A. A. Berle, Jr.), 5 May 1941; Note by the Assistant Chief of the Division of Near Eastern Affairs (Paul H. Alling), n.d.; Memorandum by the Chief of the Division of Near Eastern Affairs (Wallace Murray), 7 November 1941; Memorandum by the Under Secretary of State (Sumner Welles) to the Secretary of State (Cordell Hull), 15 November 1941; Foreign Relations of the United States 1941 (Washington, 1959), III, pp. 171, 176, 184-7. 
conscious people in countries like India, who had little awareness of the low level of his interest in their anti-colonial struggles. Since the propaganda dividends that the United States reaped in the colonial areas were substantial, the Roosevelt Administration was content to leave its pronouncements lofty and vague. In August 1941, Roosevelt had joined Churchill in proclaiming the Atlantic Charter. Paragraph 3 of the "Charter" proclaimed their solemn resolve "to respect the right of all people to choose the form of government under which they will live" and their desire "to see sovereign rights and self-government restored to those who have been forcibly deprived of them". Churchill subsequently announced, without any public protest from Roosevelt, that the Atlantic Charter did not apply to India. Indian nationalists were baffled by the President's silence, but their appraisal of him was so favourable that they continued to hope that he would set Churchill right before too long.

America's own involvement in the war and the dramatic collapse of the British position in Southeast Asia led to some re-thinking on the Indian issue by the Roosevelt Administration. It was felt that developments in India could have a significant bearing on the military objectives of the United States in the Asian theatre of war. Roosevelt sought, for the first time, to raise the question of India's political future in a discussion with Churchill. Churchill recounts in The Second World War that he had "reacted so strongly and at such length" that Roosevelt "never raised it verbally again". 1

As the military situation worsened and as the forces of Japan swept northwards through Burma, Roosevelt named Louis A. Johnson as his Personal Representative in India. The President's interest in a political settlement in India at this time - which coincided with the mission of Sir Stafford Cripps - arose mainly on the basis of his appraisal that such a development might have a favourable impact on the military situation. When the Cripps Mission failed and when Churchill assured Roosevelt that the military situation demanded a continuance of the status quo in India, the President did not choose to press his suggestion for the setting up of a temporary Dominion Government in India. "The position in India is largely military", he declared, while politely but firmly directing Louis Johnson to give up his quest for a "formula" to promote a settlement in India. ${ }^{2}$

1 Winston S. Churchill, The Second World War (London, 1951), IV, p. 187.

2 This argument is developed in M.S. Venkataramani, Undercurrents in American Foreign Relations (New Delhi, 1965), pp. 4-5. For a detailed discussion of developments during this period, see M.S. Venkataramani and B. K. Shrivastava, "The United States and the Cripps Mission", in: India Quarterly (New Delhi), 19 (July-December 1963). 
Resentment towards Britain mounted in India and nationalists led by Gandhi came round to the fateful decision that if the alien rulers persisted in their refusal to work out a mutually acceptable settlement, a mass movement should be launched against continued British rule. "Quit India!" was the slogan that Gandhi coined, and it was endorsed by the Congress Party on 8 August 1942. The following day the British Indian authorities arrested Gandhi, Nehru, and scores of other Congress leaders.

President Roosevelt did not like the timing of the "Quit India" demand nor the nature that the movement assumed after the arrest of the nationalist leaders. He was of the view that "irrespective of the merits of the case, any action which slows up the war effort in India results not in theoretical assistance, but in actual assistance to the armed forces of Japan". He was, therefore, completely opposed to Generalissimo Chiang Kai-shek's plea that he should make an attempt to persuade Britain to revise its course in India. The President decided on a policy of silence. "I think", he wrote to Chiang, "that you and I can best serve the people of India at this stage by making no open or public appeal or pronouncement but by letting the simple fact be known that we stand ready as friends to heed any appeal for help if that appeal comes from both sides." 1 But, as Roosevelt knew well enough, the leaders of the Indian Congress were held incommunicado and the British Prime Minister would be the last person to "appeal" to the United States for "help" in effecting a settlement in India. Roosevelt, however, retained his interest in the military implications of any major unrest in India and in the winter of 1942 he decided to depute a senior American diplomat, William Phillips, to serve in New Delhi as the Personal Representative of the President.

\section{GANDHI DECIDES TO FAST}

Meanwhile, in his palace-prison in Poona, Gandhi had been engaged in an agonized appraisal of the situation in India and had finally reached a fateful decision. Having become convinced that his people were succumbing to a mood of defeatism and desperation and that the British authorities were implacable in their attitude, the Mahatma informed the British Viceroy that the only course left open to him was to "crucify the flesh by fasting".

Gandhi had fasted before for causes that he had considered profoundly important - promotion of Hindu-Muslim unity, prevention of

1 Franklin D. Roosevelt to Chiang Kai-shek, 12 August 1942, Foreign Relations of the United States 1942 (Washington, 1959), I, pp. 715-7. 
attempts to split the so-called "untouchables" away from the main body of Hindus, atonement for acts of violence by his people, and selfpurification. These ordeals, derided by many in India and outside, nevertheless had a profound, if seemingly temporary, impact on countless thousands of his countrymen.

To Gandhi fasting was a weapon of last resort. He was not the inventor of the technique which had been in use from times immemorial as a means of penance, defiance against arbitrary authority, rallying one's supporters, and inducing an oppressor eventually to change his ways. Gandhi believed that fasting stirred up "sluggish consciences and fires loving hearts to action". It was his conviction that no radical changes could be brought about in society except by creating a ferment. $\mathrm{He}$ preferred to accomplish the process through non-violence, rather than violence. "Non-violent pressure exerted through self-suffering by fasting ... touches and strengthens the moral fibre of those against whom it is directed", Gandhi believed. ${ }^{1}$ The object of fasting, according to Gandhi, was not to cause or even intend any injury to the wrongdoer. "The object always is to evoke the best in him. Self-suffering is an appeal to his better nature, as retaliation is to his baser."2

Gandhi's fast in jail in February-March 1943 was an attempt to infuse some spirit and resistance in the hearts of his countrymen and, also to strengthen the moral fibre of the Western leaders so that they might realise the justice of the Indian demand for freedom. The freeing of India, the Mahatma had argued in the days before his arrest, would place the Allied cause on an "unassailable basis". If India became free, he had declared, the end of imperialist exploitation in Asia and Africa and of racial discrimination in the United States and elsewhere would follow, thereby making real the professed war aims of the United Nations.

In the final analysis Gandhi's fast was aimed partly at bringing pressure to bear on Winston Churchill and Franklin Roosevelt, leaders of the democratic nations. Of them, Churchill had for long regarded himself as the implacable foe of "Gandhi, the Indian Congress and all they stand for". He had enthusiastically and vigorously supported

1 Quoted by Pyarelal, a close associate and secretary of Mahatma Gandhi, "Gandhiji's Satyagraha: Its Technique and Application", in: Gandhian Outlook and Techniques (New Delhi, 1953), p. 387. For a brief account of the concept and history of fasting see A.M. Hocart, "Fasting", in: Encyclopedia of the Social Sciences (New York, 1931), VI, pp. 144-6.

2 M. K. Gandhi, "Fasting in Non-Violent Action", in: Harijan (Ahmedabad), 26 July 1942, p. 248. The article as well as several others written by Gandhi on the theme of fasting are brought together in M. K. Gandhi, Fasting in Satyagraha (Ahmedabad, 1965). 
the action of the Viceroy in arresting the leaders of the Indian National Congress and in putting down the widespread disturbances that followed in the wake of the arrests. In a speech in London's Mansion House on 10 November 1942 Churchill had declared:

"Let me, however, make this clear, in case there should be any mistake about it in any quarter. We mean to hold our own. I have not become the King's First Minister in order to preside over the liquidation of the British Empire."1

Among the far-flung "possessions" of His Brittanic Majesty, none was closer to Churchill's heart than India. It was the "brightest jewel" in the British Crown and the Prime Minister was not willing to part with it because a "naked fakir" threatened to go hungry for three weeks. What, then, was the attitude of the President of the United States, engaged as he was in leading his country in a great war that involved mass carnage, to the problem posed by the possible death by starvation of one human being - a prisoner of the British Raj.

\section{PHILLIPS EXAMINES GANDHI-LINLITHGOW CORRESPONDENCE}

One day, early in February 1943, the Personal Representative of the President of the United States in India had an appointment with His Excellency the Marquis of Linlithgow, Viceroy and Governor General of India. The envoy was William Phillips, one of the most senior and respected members of the American diplomatic corps and a personal friend of President Roosevelt. His posting to New Delhi had been enthusiastically greeted by the British press because Phillips was known as a lifelong Anglophile. Indeed wags in the Department of State used to say that if Phillips were ever confronted with the problem of choosing between going to heaven and being named as Ambassador to the Court of St. James, he would have unhesitatingly opted for the latter.

Contrary, to the belief of many Indians, Phillips' deputation to India was not arranged by President Roosevelt as a defiant expression of sympathy towards the nationalists and their demand for freedom from British rule. With the turning of the tide of war in Africa, the problem of the coming struggle against the Japanese came to attract growing attention on the part of American policy-makers. Since India

1 Churchill's comment on Gandhi and the Congress is quoted in Jawaharlal Nehru, Discovery of India (London, 1960), pp. 446-7. Text of the Mansion House speech in Charles Eade, comp., The War Speeches of the Rt. Hon. Winston S. Churchill (London, 1952), II, pp. 341-5. 
was an important base and since the war against Japan was expected to be protracted, the American leaders thought it prudent to send a senior diplomat to Delhi to take a close look at the military and political developments in that part of the world. Britain ruled India and American leaders were very anxious not to offend the British. It was not surprising, therefore, that the man whom Roosevelt selected for the Delhi post happened to be one who enjoyed excellent relations with the top echelons of the British Government - William Phillips.

Five weeks in India and long talks with the Viceroy, high British and Indian officers, and a variety of Indian politicians had a tremendous impact on Phillips. The American was repelled by the arrogance of British officialdom, and the sycophancy and servility of the Indian officials and politicians who were its lackeys. The idea of such a coterie holding an ancient people in thralldom made this sensitive Bostonian aristocrat increasingly uncomfortable. This did not mean that he swung over to a position of espousing the cause of Gandhi and Nehru. Five weeks in India, however, had made him a puzzled and troubled man - a man whose faith in British justice and British fair play was beginning to be undermined.

It was such a man whom Linlithgow informed in all confidence that Gandhi was about to begin a fast. The Viceroy gave the American envoy a copy of the correspondence that had passed between him and Gandhi. In Phillips' long experience as a diplomat it was unlikely that he had ever read letters like those that the Indian prisoner wrote to his Chief British Jailor, the Viceroy.

Gandhi appears to have experienced ever-growing mental anguish as he contemplated the prospect of a prolonged period of incarceration for himself and thousands of Congressmen belonging to every part of India. Governmental repression as well as acts of violence by angry Indians were a source of great sorrow to him. Had his leadership been grievously at fault? With an aggressive enemy knocking at the gate and an alien ruler imposing his will on Indians in their own home, his leaderless people had been reduced to a worse plight than ever before. If he had failed his people, it was he who must subject himself to an appropriate act of penance. But before taking any such step he would try his best to make the British authorities realize that "they had wronged innocent men". He would persevere in this quest for six months before adopting an alternate course. Such appears to have been the trend of Gandhi's thinking as revealed in his letters to the Viceroy.

The Mahatma wrote his first letter to the Viceroy within a few days after his arrest on 9 August 1942. Urging the Government of India to reconsider its course, Gandhi said that it had been wrong in precipitating the crisis instead of awaiting his promised letter which was to have 
been an appeal for an impartial examination of the Congress case. "Do not disregard the pleading of one who claims to be a sincere friend of the British people", he declared. Linlithgow responded curtly that the Government of India was not disposed to accept either Gandhi's criticism or his request for a reconsideration of its policy. ${ }^{1}$

Over a month later Gandhi wrote to the Additional Secretary of the Home Department contending that, deplorable as the outbreaks of violence in various parts of India were, the responsibility rested squarely on the Government of India. Its precipitate action in arresting the Congress leaders had given rise to the "leonine violence" of the infuriated populace. The Mahatma appealed to the Government "to release the Congress leaders, withdraw all repressive measures and explore ways and means of conciliation". ${ }^{2}$ To this communication there was no response from the Government.

Weeks and months rolled by. On New Year's eve Gandhi addressed a solemn letter to Linlithgow. He had waited in vain for six months hoping for a change in the heart of the rulers, Gandhi wrote. What then could be his future course? "The law of Satyagraha as I know it prescribes a remedy in such moments of trial. In a sentence it is 'crucify the flesh by fasting'. That same law forbids its use except as a last resort. I do not want to use it if I can avoid it."

The Viceroy had it in his power to avert the fast, Gandhi wrote.

"This is the way to avoid it, convince me of my error or errors and I shall make ample amends. You can send for me or send someone who knows your mind and can carry conviction. There are many other ways if you have the will. May I expect an early reply? May the New Year bring peace to us all."

Nearly two weeks later Linlithgow replied to the prisoner's appeal. He could take note of any suggestion, he said, only if Gandhi agreed to retrace his steps, condemn the widespread violence that his partisans had instigated, and dissociate himself from "the policy of last summer". To this demand the Mahatma's answer was that he could not condemn any action simply on the basis of one-sided information. Emphasizing that he had no mental reservation of any kind, he amplified his earlier suggestion for reconciliation. Wrote Gandhi:

1 M.K. Gandhi to Lord Linlithgow, 14 August 1942; Linlithgow to Gandhi, 22 August 1942; in: Correspondence with Mr. Gandhi, August 1942 - April 1944 (New Delhi, 1944), pp. 1-3.

2 Gandhi to the Additional Secretary, Home Department, Government of India (Sir Richard Tottenham), 23 September 1942, ibid., pp. 3-4. 
"If you want me to act singly, convince me that I was wrong and I shall make ample amends. If you want me to make any proposal on behalf of the Congress, you should put me among the Congress Working Committee members. I do plead with you to end the impasse."1

The Viceroy responded to the appeal in a peremptory way. Gandhi should repudiate the All India Congress Committee's resolution of 8 August 1942 calling on the British to withdraw from India. Gandhi should give the Viceroy "appropriate assurances" of good behaviour for the future. "I should make that clear in the plainest possible terms", the Viceroy asserted. If the demands were complied with, His Lordship would be willing "to consider the matter further".

Gandhi replied in a tone of sadness and resignation. He had failed to get "soothing balm for my pains" and he had thus no other alternative except to "resort to the law prescribed for Satyagrahis, namely, a fast according to capacity". He had no wish to undertake a fast unto death, the Mahatma emphasized. He would like to survive the ordeal, "if God so wills". The fast would last 21 days. $^{2}$

The Viceroy was well aware of the complications that might ensue if Gandhi were to die in a British prison. In a very shrewd move, he offered to release the prisoner for the duration of his fast and to permit him to go to any place of his choice. Gandhi responded, with equal shrewdness, that there would be no fast if he were released since he would survey the situation de novo and decide on his future course of action.

Here again was an opportunity that the Viceroy might have taken advantage of, had he been disposed, to bring about a resumption of negotiations. He was, however, determined not to yield an inch and Gandhi was informed that there was no question of his release except for the duration of the proposed fast. ${ }^{3}$

And the Viceroy taunted the imprisoned Mahatma on the decision that he had taken. The fast was a form of coercion, of political blackmail for which there could be no moral justification, Linlithgow wrote. It was nothing but "an attempt to find an easy way out" and to escape the judgment of the world.4

1 Gandhi to Linlithgow, 31 December 1942, ibid., p. 5; Linlithgow to Gandhi, 13 January 1943; Gandhi to Linlithgow, 19 January 1943, ibid., pp. 5-7.

2 Linlithgow to Gandhi, 25 January 1943; Gandhi to Linlithgow, 29 January 1943, ibid., pp. 7-8.

3 Gandhi to Tottenham, 8 February 1943; Tottenham to Gandhi, 9 February 1943, Gandhiji's Correspondence With the Government 1942-44 (Ahmedabad, 1945), pp. 49-50.

4 Linlithgow to Gandhi, 5 February 1943, in: Correspondence with Mr. Gandhi, pp. 4, 9-11. 
As the Personal Representative of the President perused this correspondence, he might well have found it difficult to comprehend Gandhi's reasoning or his projected action. His initial reaction was that a fast by Gandhi would simply complicate matters by making it more difficult for Britain to initiate any new move since such a course might be interpreted as submission to Gandhi's threats. On the other hand, Phillips could not have failed to take note of Gandhi's unmistakable desire for reconciliation and for a fresh examination of the situation. Assurances to that effect were conveyed to Phillips on 9 February by two members of the well-known family of industrialists, the Birlas, and by Devadas Gandhi, son of the Mahatma and editor of the Hindustan Times. They had stressed that if the British Government acted in good faith, the Indian leaders would be entirely willing to meet it "in a spirit of friendly accommodation".

That Linlithgow could be dour and stubborn was by now known to Phillips on the basis of his own personal experience. The same kind of obstinacy he could see in a press communique that the Government of India proposed to release if Gandhi started a fast. The Viceroy had furnished Phillips with an advance copy of the communique which characterized as "preposterous" Gandhi's statement that the acts of violence that had taken place were due to the Government's hasty action in arresting the Congress leaders. The Government would not release Gandhi nor would they allow the fast to deflect it from its course. The responsibility for any fast and its consequences rested exclusively with Gandhi, the communique stated. Could it be, Phillips wondered, that the Viceroy was dedicated to the maintenance of British "prestige" and opposed to any conciliatory course? "Reluctantly I am coming to the conclusion", Phillips reported to the Secretary of State, "that the Viceroy, presumably responsive to Churchill, is not in sympathy with any change in Britain's relationship to India."1

\section{ENVOY SEEKS GUIDANCE FROM WASHINGTON}

The news that the Mahatma had started a fast caused consternation among the Indian people. Only the most hardened leaders of the Muslim League and the most ardent collaborators with the British were able to scoff at Gandhi's ordeal. Informed Indians were convinced that Britain was unlikely to release Gandhi and they were thus deeply

1 The Personal Representative of the President in India (William Phillips) to the Secretary of State (Cordell Hull), 10 February 1943, Foreign Relations of the United States 1943 (Washington, 1964), IV, pp. 187-8. This source will hereafter be cited as FR 1943, IV. Text of the Government of India's communiqué in Devadas Gandhi, comp., India Unreconciled (New Delhi, 1943), pp. 105-7. 
perturbed. In their state of utter helplessness, they turned to the one man who, they fondly hoped, might yet be able to save the life of the Mahatma - the Personal Representative of the President of the United States.

On 11 February 1943 Phillips was the chief guest at a lunch at the Gymkhana Club given by a journalist. Many members of the Viceroy's Executive Council and several leading officials attended. Before the guests were seated, Sir Joginder Singh, a member of the Council, took Phillips out into the garden and earnestly asked whether the United States could not use its good offices to bring about Gandhi's release. Phillips was deeply impressed by Singh's concern and he sent a telegram to Washington reporting the conversation. In the night the envoy attended a dinner at the residence of another Indian member of the Viceroy's Council, Sir Homi Mody. Phillips heard from an unidentified source that the Viceroy's Council had upheld Linlithgow's policy by a majority of 6 to 5 and that all the three British Members had voted with the majority. Phillips also learned that at least two persons who voted against the Viceroy's policy might submit their resignations.

The following day Phillips received a call from $\mathrm{K}$. Srinivasan, Editor of the The Hindu, an important newspaper published from Madras. The modest and sober Srinivasan pleaded with the envoy to initiate some steps by which the danger to Gandhi's life could be averted. A similar plea was made by G. D. Birla. ${ }^{1}$ To such appeals Phillips was unable to give any clear response. "Washington was being daily advised" was all that he could tell them. In the absence of any instructions from the State Department he could not make any sort of public announcement on the fast. Some Indian newspapers were angered by the silence of the American envoy. The Bombay Chronicle pointedly asked whether Phillips had raised even his little finger to protest against British policy in India. It wanted to know whether President Roosevelt would ignore violations of his lofty ideals if they were visited upon non-White peoples.

Phillips was greatly exercised over such comments and was anxious not to give any impression to the Indians that the presence of American troops and of a representative of the President in India constituted any American endorsement of British policies in the country. His problem was how he could convey his sentiments to the Indian public without offending the British. The instructions that Secretary Hull had given him forbade any action that might be regarded as objectionable by the British. Did those instructions still stand or would the Secretary desire

1 Diary entries, 11, 12, 13 February 1943, Indian Diary II, Papers of William Phillips, Houghton Library, Harvard University, Cambridge, Mass., USA. 
to modify them to meet the new developments? Phillips explained his predicament to Hull and pleaded for guidance. ${ }^{1}$

The problem posed by the harried envoy was extremely urgent, with ramifications that might extend into the future. But at such a time President Roosevelt was thinking in terms of a leisurely visit to the United States by Phillips some time in April or May 1943. On February 15, five days after the beginning of Gandhi's fast, the President sent the following message to the Secretary of State: "In view of the fact that William Phillips is getting pretty well oriented in regard to the general situation in India, will you please wire him that I would like to see him in Washington the end of April or the beginning of May, and that he can get a chance to be in this country about a month?"

To his Personal Representative who was urgently pleading for "guidance" Roosevelt wrote the following letter on 16 February $1943:^{2}$

It is grand to find yours of January twenty-second on my return from Casablanca. You must be having a very exciting time.

I sent word to the State Department yesterday to ask you to come back here about the end of April or the beginning of May because I want a personal check-up on the situation at about that time - and I think you could safely plan to be here for a month before returning.

If the middle or end of May is more convenient for you, do it that way.

My best to you,

As ever yours,

(Sd.) Franklin D. Roosevelt

From these developments it can reasonably be inferred that while one week had passed since Gandhi commenced his fast, the President was not specially exercised over it. Neither he nor the Secretary of State was desirous of sending any new instructions to the envoy in New Delhi.

1 The Personal Representative of the President in India to the President, 11 February 1943; to the Secretary of State, 12 February 1943; FR 1943, IV, pp. 188-91, 191-2.

2 Memorandum from the President to the Secretary of State, 15 February 1943, Official File (OF) 48-H, Roosevelt, Papers of Franklin D. Roosevelt, Franklin D. Roosevelt Library, Hyde Park, New York, USA. Roosevelt to Phillips, 16 February 1943, OF 2314, ibid. On the same day, 16 February, Hull informed Phillips by telegram concerning the President's desire that he should return to the United States. It is from this telegram that a possible clue may be found to the puzzling action of Roosevelt. Hull indicated that the President's move had reference to the concluding paragraph of Phillips' letter to the President dated 12 February. The paragraph referred to comprised of a single sentence and it read: "Any guidance which you can give me will be appreciated." The Secretary of State to the Personal Representative of the President in India, 16 February 1943, FR 1943, IV, p. 194. 
From the reports of Phillips the American leaders knew that the Government of India had imposed a severe censorship on news relating to the fast and to the reaction of the Indian people towards it. Representatives of all American news media in India requested Phillips to use his good offices on their behalf and he informally communicated to the Ministry of External Affairs of the Government of India their protest "in not being allowed to present to the American public a true account of the present conditions here".

The result of the envoy's representation was the very opposite of what the American newsmen had hoped for. Two days later Sir Reginald Maxwell, Home Member in the Viceroy's Executive Council, summoned the correspondents and told them emphatically that the Congress was "the enemy" and that they would not be permitted to send out any despatches that placed the Congress or Gandhi in any favourable light. ${ }^{1}$

As a result of such rigid censorship, the coverage of the fast in the American press was far less adequate than might have been the case under more normal circumstances. Nevertheless, the basic facts concerning the fast itself were published in the American press. Barring the "old faithfuls", few persons or groups endorsed Gandhi's cause or demanded his release.

Once again American Socialists refused to remain silent. Norman Thomas, Harry Fleischman, Travers Clement, and Samuel Friedman, representing the Action Committee of the Socialist Party, called upon President Roosevelt "to make a down payment on the promissory note of the Four Freedoms" by urging Churchill to release unconditionally Gandhi and the thousands of other Indian political prisoners. The Executive Committee of the Fellowship of Reconciliation, an organization of pacifists, made a similar appeal to the President. If Britain and the United States failed to avert such a calamity as Gandhi's death, people around the world would be profoundly shocked, the appeal stated. ${ }^{2}$ Novelist Pearl Buck, Robert Bendiner, managing editor of the Nation and thirteen others begged the President to act immediately to seek Gandhi's release. Gandhi's death would be a tragic blow to the faith of people everywhere in the war aims of Britain, declared the National Association for the Advancement of Colored People, in a

1 The Personal Representative of the President in India to the Secretary of State, 13 February 1943; 15 February 1943; FR 1943, IV, pp. 192-3. Emphasis added. 2 New York Times, 19 February 1943, p. 8. A. J. Muste, executive secretary of the Fellowship of Reconciliation, to the President, 24 February 1943, 845.1907, Files of the State Department, National Archives, Washington, DC, USA. 
cable to Churchill. On the West Coast, Harry Bridges, leader of the longshoremen's union, called for immediate American action to stem the crisis in India. The President of the India League of America, J. J. Singh, appealed to Roosevelt "to use your great influence with Prime Minister Churchill and save Gandhi's life". ${ }^{1}$

In New Hampshire, Corbett Bishop, a 37 year old conscientious objector commenced a 21-day fast as soon as he heard of Gandhi's fast. About fifty persons in Corning, New York, fasted on 25 February in sympathy with the Indian leader. Two ministers who had served as missionaries in India, the Rev. Ralph Templin and the Rev. J. Holmes Smith, were arrested by the police in the nation's capital as they attempted to picket the British Embassy. ${ }^{2}$

In the files of the Department of State are to be found about twenty letters from individuals and groups appealing to the President or the Secretary of State to take urgent measures to secure the release of the Indian leader. The small number of the communications is an indication of the virtual absence of widespread public concern over the fast and the possibility of Gandhi's death. ${ }^{3}$

No important American newspaper extended firm support to Gandhi's stand. Some like the Chicago Tribune were critical of what they regarded as extreme stubbornness on the part of the British. Others

1 Hindustan Times (New Delhi), 22 February 1943, p. 1; The Hindu (Madras), 25 February 1943, p. 4; New York Times, 25 February 1943. Among those who signed Pearl Buck's appeal to Roosevelt were Richard J. Walsh, Bruce Bliven, John L. Childes, George S. Counts, Reinhold Niebuhr, James Loeb Jr., William E. Bohn, Mark Starr, Thomasine Campbell, Dorothy Norman, Nathaniel Minkoff, Morris Shapiro, Alfred Baker Lewis, Edward Heiman, and Frank McCullogh. Buck's efforts are described in Richard J. Walsh to J. J. Singh, 20 February 1943, Papers of J.J. Singh, Indian School of International Studies Library, New Delhi, India. Also Singh to Roosevelt, Churchill, Halifax, and Chiang Kai-shek, n. d., February 1943, telegrams, ibid.

2 New York Times, 24 February 1943, p. 9; 5 March 1943, p. 21. Lea Springs and others of Corning, New York, to the Secretary of State, 24 February 1943, 845.00/1824, Files of the State Department.

- Among the communications that the President received was one from V.K. Krishna Menon. He appealed to Roosevelt to use his "immense influence" to secure the release of Gandhi and thereby avert a calamity whose consequences would be incalculable. V.K. Krishna Menon to the President, 21 February 1943, 845.00/1831, Files of the State Department. Menon communicated to the President a resolution adopted at a meeting of the Indian community in London. In the files made available by the State Department to Venkataramani only one other communication from abroad relating to the fast was found. It was an appeal to the President to use his good offices to save the life of Gandhi and it was signed by Salvador Allende, Secretary of the Socialist Party of Chile, and representatives of several other Chilean organizations. Salvador Allende and others to the President, 23 February 1943, 845.00/1790, ibid. 
like the Chicago Sun and the New York Times expressed concern that the British might find themselves in a difficult situation in India if Gandhi were to die in prison. Still others sought to evaluate the fast in relation to the war situation in Asia and the role of the United States in that theatre. The Philadelphia Record and some of the ScrippsHoward newspapers argued that in view of America's stake in the outcome of the war in the East, it had the right to expect that the British would take steps "to change sullen India into a fighting ally".1

Several newspapers like the New York Herald Tribune endorsed the British position in its entirety. The fast, said that newspaper, was nothing more than political blackmail. It had "no meaning or relevance to the world in which we live" and it had been undertaken to "restore a failing leadership". To release Gandhi "would be a disastrous surrender, and particularly dangerous under the peril of the war". The Herald Tribune concluded that "it would be folly to suppose that there is any magic way of intervening to prevent its ineluctable development."2

The Christian Science Monitor was even more angry with Gandhi than its New York contemporary. It referred contemptuously to the fast as "political hunger", and added that in taking such a step "Mr. Gandhi is waging war by his own peculiar methods against Britain in India, and indirectly against the United Nations cause there."3

By this time the Chicago Daily Neres had fallen into the habit of characterizing the Indian nationalists and especially Gandhi in terms of utter contempt. Gandhi's fast was a stunt that was not even hazardous, the newspaper declared. Despite the ballyhoo, all that the man was doing was to spend 21 days comfortably in his bed, drinking fruit

1 Survey of press opinion, in Acting Secretary of State (Sumner Welles) to the United States Mission in New Delhi, 27 February 1943, 845.00/1790, ibid. The Chicago Sun urged that Gandhi should be released unconditionally. "The fact remains that if he died a martyred prisoner, the bad situation becomes incalcuably worse", it declared. Excerpts in The Hindu, 24 February 1943, p. 4. Columnist Ludwell Denny wrote that the United States could not ignore the implications of Britain's handling of the situation posed by Gandhi's fast. The issue was not Gandhi, but the war effort, he declared. "Americans have a right to expect the British government to make every effort to change a sullen India into a fighting ally for our common freedom." Ludwell Denny, "Allies Need India", in: New York World Telegram, 1 March 1943. Also Nation (New York), Vol. 156 (20 February 1943), p. 354.

2 Ed., "Mr. Gandhi's Fast", in: New York Herald Tribune, 14 february 1943; ed., "If Gandhi Dies", ibid., 22 February 1943. The correspondent of the newspaper in India, Sonia Tamara, presented a more balanced picture in "Two Philosophies Clash in India", ibid., 24 February 1943.

"Ed., "Political Hunger", in: Christian Science Monitor (Boston), 24 February 1943. 
juices. Gandhi was not in any kind of danger since he had conserved his energies for many years and refrained from exposing himself to the debilitating effects of labour. "Many people throughout the world will, therefore, refuse to sit up nights to await bulletins from the Mahatma's bedside", declared the Daily News. ${ }^{1}$

In a telegram to Phillips on 27 February 1943, Under Secretary of State Sumner Welles evaluated American press reaction to Gandhi's fast. Comments on the issue were factual and scanty, he stated. Occasionally a small town paper condemned Britain unequivocally. But most of the newspapers were of the view that the trouble was of Gandhi's own making and that little sympathy need be shown to him. The New York correspondent of the London Daily Mail sent a report on similar lines to his newspaper. "To the great majority of Americans Gandhi's fast is a simple form of blackmail and both the public and press deplore it", he wrote. ${ }^{2}$

There was no significant domestic pressure on the Roosevelt Administration to exert itself in order to secure Gandhi's release.

\section{"ACTION FOR THE RECORD"}

While British censorship kept the American public unaware of the sentiment in India over Gandhi's fast, Phillips had kept the President and the Secretary of State fully informed. The envoy could not remain unmoved by the fervent hope and anxious expectation with which many Indians looked to him and to his country for some positive step. On 11 February 1942 he conveyed to the President a sense of his own helplessness:

"Unhappily for me, more and more attention seems to be centered upon this Mission and upon me personally. Every Indian who comes to see me feels that through my influence the present deadlock with the British can be solved. Naturally, I am in the picture because of the popular feeling that the President of the United States alone can bring any influence to bear upon the British Government."

Phillips informed Roosevelt that the Viceroy himself was deeply concerned that Gandhi might not survive the strain of the fast. The envoy then cautiously stressed the urgent need for a new approach by Britain, without touching on the ticklish question of an initiative

1 Chicago Daily News, 26 February 1943.

2 Survey of press opinion, loc. cit.; Daily Mail (London), 25 february 1943. 
by the President himself to promote such a course. Phillips declared emphatically that "the key to the present problem is in the hands of the British Government" and that it would be wise for Churchill "to unlock the door." Wrote the envoy:

"... the unanimous demand for a new approach on the part of the British Government is a matter of extraordinary interest which I only wish I could convey to you far more satisfactorily than I am doing, but which is almost impossible to present by letter. I feel acutely the fact that public attention is centered upon me in the hope and even expectation that I can do something constructive, and yet here I am, quite unable to do anything but listen to appeals, realizing as I do the importance of not prejudicing my position with the British authorities."1

Phillips also included in his communication to the President a concrete suggestion for action by the British Government to resolve the deadlock in India.

On 12 February Phillips emphasized, in a cable to the Secretary of State, that it was "important ... to avoid giving any impression to the Indians that, through silence and inaction as well as through the presence of United States Forces and myself, strength is being added to the British position." However, as he set down in his diary the developments of the day, the envoy did not feel very hopeful that the State Department might adopt a positive attitude. "I wish the Department would give me some hint as to their own views," he wrote, "but, of course, they never do this in ticklish times". ${ }^{2}$

Hull was not ready, at this time, to recommend any modification of the American policy which was described by Phillips himself as one of "silence and inaction". He did raise the issue of Gandhi's fast when the British Ambassador, Lord Halifax, called on him on 16 February. In a circuitous fashion and after disclaiming any intention "to make ... suggestions or to pass judgement on anything involved", the Secretary posed the issue in a most remarkable manner. Hull stated that it had occurred to him that "if Gandhi should die during his present fasting there might arise acute conditions which it would be important to foresee and to prepare against ...." Having thus clearly demonstrated his friendly solicitude, Hull asked whether the British might find it

1 The Personal Representative of the President in India to the President, 11 February 1943, FR 1943, IV, pp. 188-91.

2 Personal Representative of the President in India to the Secretary of State, 12 February 1943, ibid., pp. 191-2. Diary entry, 12 February 1943, Indian Diary II, Phillips Papers. 
possible and advisable "to consider certain additions to the Cripps proposals". 1

The Secretary might well have been of the opinion that he had done his best under the circumstances that he confronted. But late in the same night there arrived in the State Department an urgent telegram from Phillips addressed jointly to the President and the Secretary. The envoy reported that according to information confidentially received from Sir Sultan Ahmed, Law Member in the Viceroy's Executive Council, Gandhi's condition had become very grave and that he might die in a few days. Sir Sultan and four other members of the Council, deeply disturbed over the development and unwilling to appear before the Indian people as responsible for Gandhi's death, had attempted to see the Viceroy but had failed.

Phillips then raised the question of how the United States would appear to the Indian people if Gandhi were to die in prison. In vain he had pleaded for guidance, but time seemed to be running out and there was nothing to indicate that America had not remained indifferent. Wrote Phillips:

"It would be helpful for me to know whether the President would be willing to allow me, in the event it is learned that Gandhi's life is in imminent danger, to approach the Viceroy informally and express our deep concern over the political crisis.

Even though there might be no immediate results, perhaps such action might be useful for the record because it would help to correct the impression, based on our inactivity and the presence of American troops, that we have been giving support to the Viceroy's position.",

Here was a suggestion of the type that commended itself to Roosevelt

1 Memorandum of Conversation with the British Ambassador (Lord Halifax), by the Secretary of State, 16 February 1943, FR 1943, IV, pp. 194-5.

2 The Personal Representative of the President in India to the Secretary of State, 16 February 1943, ibid., pp. 193-4. Emphasis added. Phillips received the information from Herbert Matthews of the New York Times. The correspondent told Phillips that it had been indicated to him that Sir Mohammed Usman, Law Member of the Viceroy's Council, was anxious that Phillips should convey a message from four Members of the Council to the Viceroy whom they could not reach. Phillips sent word to Usman through Matthews that he would call on Usman if invited to do so. When Matthews communicated this information to Usman, the latter, after conferring in private with some colleagues, told the former that he would write to Phillips "tomorrow". Phillips had no intention of carrying out the assignment, but he thought it was best to show willingness to call on Usman if the latter invited him to do. Diary entry, 16 February 1943, Indian Diary II, Phillips Papers. 
and Hull. "The President and I concur in your suggestion that you approach the Viceroy informally and express our deep concern over the political crisis", Hull cabled. The crux of the crisis, in Hull's mind, was still the aftermath of Gandhi's death. He asked Phillips to convey, in his discretion, "an expression of our hope that some means may be found to avert the worsening of the situation which would almost certainly follow Gandhi's death". ${ }^{1}$

Hull could not have been unaware of the fact that any such discreet communication from Phillips to the Viceroy was hardly likely to bring about a change in British policy. Churchill might proclaim tirelessly that important decisions relating to India were made by the Government of India, by the Viceroy's Council in which Indians constituted a decisive majority and so on. But the facts were different as Phillips knew only too well. Hence it would have come as no surprise to Phillips when, in fulfilling his assignment on 18 February, he was informed by the Viceroy that the final decision "on all such matters as Gandhi's fast" remained with London. The Ambassador was, however, sorely disturbed by other comments made by the Viceroy which indicated a total unwillingness to change his course.

Linlithgow asserted that he, as well as the Government in London, were fully convinced of the rightness of their course and that they "faced with equanimity the possibility of Gandhi's death ...." If Gandhi did die, there might be some trouble but he was confident that he could overcome it without great difficulty. In about six months the situation would clear up and "progress made easier". ${ }^{2}$ It was apparently the Viceroy's settled conviction that Gandhi's passing would contribute to "progress", for he stressed that it was Gandhi who had sabotaged all efforts in that direction undertaken by the British Government.

Neither the Indian nor the American press correspondents knew about Phillips' meeting with the Viceroy. The envoy felt that if at least he could tell the press that he had called on the Viceroy, the pressure on him and criticism directed at the United States might be mitigated. But when he sought the Viceroy's permission he was informed in the most

1 The Secretary of State to the Personal Representative of the President in India, 17 February 1942, FR 1943, IV, p. 195.

2 Personal Representative of the President in India to the Secretary of State, 18 February 1943, ibid., pp. 195-6. With characteristic British thoroughness, the authorities stockpiled in Poona quantities of sandalwood and other materials for possible use to cremate Gandhi. The route for the funeral procession has also been decided. Officials all over the country had been directed to suppress any disturbances that might break out following Gandhi's death. On this point, see Madeleine Slade (Mira Behn), The Spirit's Pilgrimage (New York, 1960), p. 252. Slade, a long-time follower of the Mahatma, was an inmate of the Aga Khan Palace. 
earnest manner that an announcement even of the fact of the meeting would be "disastrous".

In a personal letter to Under Secretary Sumner Welles, Phillips described his predicament. Pressure on the Mission and on him personally to "do something" was mounting in intensity, he pointed out. The pressure was not confined to supporters of the Congress, but extended all the way to members of the Viceroy's Council. The press expected the United States to undertake some positive step. "There is more expectation than criticism against us, but the latter will develop and become serious if Gandhi dies during the fast. The Indians are likely to feel that through our 'inactivity' the British have been encouraged to pursue their intransigent attitude", he added. ${ }^{1}$

\section{RAJAJI AND SAPRU APPEAL TO PHILLIPS}

As anxiety mounted in India over Gandhi's life, a group of prominent Indians of various faiths, professions, and political beliefs met in New Delhi under the chairmanship of Sir Tej Bahadur Sapru. One of the principal figures in what came to be known as the Leaders' Conference was C. Rajagopalachari, the former Premier of Madras known popularly as "Rajiji". A veteran Congressman described by Gandhi as his "conscience-keeper", he had parted company with the Mahatma on the issue of the "Quit India" movement.

Rajaji called on the American envoy and had a long discussion with him. It was very important that the United States should make its position clear on the crisis in India, the Indian leader declared. The silence of the American Government was creating in the Indian mind the suspicion that the United States endorsed Britain's policy. The conclusion would be formed that America subscribed to the theory of White solidarity and sought the creation of a White bloc in cooperation with Britain. This would tend to draw India in the future more and more towards Japan and China and widen the breach between the coloured and non-coloured races. Earnestly Rajaji urged that the United States should take a longer range view of world developments and realize the dangers of an anti-White complex becoming entrenched in the minds of Asian peoples. Gandhi's death, he stated, would bring

1 Linlithgow was willing to permit Phillips to state that the Viceroy was keeping him "in the closest possible touch with the matter". The envoy declined the offer because he thought that such a statement would give the impression that Phillips concurred with the Viceroy's policy. The Personal Representative of the President in India to the Secretary of State, 22 February 1943, FR 1943, VI, pp. 200-1. Phillips to Welles, 17 February 1943, copy in India Diary II, Phillips Papers. 
in its wake bitter anti-British and anti-White sentiments. The Government of India, with its overwhelming coercive power, could put down any disturbances that might follow Gandhi's death, but the series of developments that were bound to ensue would be catastrophic, the Madras leader warned.

Rajagopalachari had added a new dimension to the problem that was profoundly agitating the envoy's mind. The pressure on him during that morning had been increasing "hour by hour". Not only Indian journalists but also American reporters impatiently demanded to know whether he had taken any action. An unceasing flow of telegrams and letters cluttered his table. Around noon Phillips received a long distance telephone call from Poona. The caller, an Indian corespondent, told him that the doctors gave Gandhi only 24 to 36 hours and that the responsibility for whatever happened would rest entirely on Phillips. ${ }^{1}$

Phillips was by this time convinced that if the American record were to show merely inaction in the face of the crisis, various undesirable consequences were likely to follow. Polite communications to the Viceroy had proved fruitless and had remained unknown to the outside world. Only if the President himself took the initiative in making a representation to London, he thought, could there be a prospect of averting the crisis. "I suggest", Phillips cabled the Secretary of State at 5 p.m. on 19 February, "that if the President could exert friendly pressure on the British Government through Halifax as former Viceroy, I believe our record will be strengthened. But there is no time to be lost."2

The developments of the following morning did little to lessen the envoy's anxiety. Doctors attending on Gandhi reported that his condition had become very grave. Sir Tej Bahadur Sapru visited Phillips and gave him a copy of a resolution adopted by his group of Indian leaders calling for the immediate and unconditional release of Gandhi "in the interests of the future of India and of international goodwill". ${ }^{3}$ The respected and independent-minded Sir Mirza Ismail, Diwan (Prime Minister) of Jaipur, also made a similar plea.

1 The Personal Representative of the President in India to the Secretary of State, 19 February 1943, ibid., pp. 196-7. Diary entries, 19 February 1943, Indian Diary II, Phillips Papers.

2 The Personal Representative of the President in India to the Secretary of State, 19 February 1943, FR 1943, IV, pp. 196-7.

3 The following is the text of the resolution: "This Conference representing different creeds, communities and interests in India, gives expression to the universal desire of the people of this country that, in the interest of the future of India and of international goodwill, Mahatma Gandhi should be released immediately and unconditionally. This Conference views with gravest concern 
To none of his visitors was Phillips able to offer any hope of support from his Government. "Phillips can do nothing here", Rajaji told reporters. Were Gandhi to die, there would be bitterness in India not only against Britain but against the United States as well, he added. "We looked both to the Viceroy and to America for help, but no encouragement has come from either. Our sole hope is in God", wailed G. D. Birla, the industrialist. The correspondent of the New York Times, after describing the "desperate moves of Indian leaders", predicted that those attempts "like everything that has happened in recent days will not change the situation in the slightest degree."1

Phillips himself was not unmindful of the plea of Sapru and his group. He regarded them as responsible and sensible man whose recommendation was not to be lightly dismissed. He was disturbed when he heard that the Government had banned the publication of the resolution adopted by the group in Indian newspapers or its transmission abroad by foreign correspondents. All the evidence that he had indicated ever increasing bitterness against the British. The envoy laid stress on this aspect in making another urgent suggestion to his Government. "It appears to me", he cabled Hull, "that a means of checking this [anti-British] trend might be a magnanimous gesture on the part of the King, ostensibly made at the Viceroy's request, in response to the widespread appeal of the Indian populace, for the unconditional release of Gandhi." 2

\section{ROOSEVELT'S CALL TO THE BRITISH}

Up to this time Gandhi's fast does not appear to have been viewed by the White House as a matter of grave urgency. It has already been pointed out that on 26 February the President had written to Phillips

the serious situation that will arise if the Government fail to take timely action and prevent a catastrophe." Phillips cabled the text of the resolution to the State Department. Personal Representative of the President in India to the Secretary of State, 20 February 1943, ibid., p. 198. For the proceedings of the conference see Leaders' Conference: An Authentic Account of the Leaders' Conference held at New Delhi on 19th and 20th February 1943 in respect of Mahatma Gandhi's Fast (New Delhi, 1943). New York Times (21 February 1943) carried a brief report of the proceedings on p. 21. Interviews with Sapru and Ismail described in Diary entry, 20 February 1943, Indian Diary II, Phillips Papers.

1 Rajaji's comment cited in New York Times, 21 February 1943, p. 21. Despatch of Herbert Matthews, ibid., 20 February 1943, p. 5. Birla was quoted in a despatch from New Delhi by A.T. Steele, correspondent of the Chicago Daily News, 18 February 1943.

2 The Personal Representative of the President in India to the Secretary of State, 20 February 1943, FR 1943, IV, pp. 197-8. 
asking the latter to plan a visit to the United States in April or May. The letter contained no reference to the fast. In the State Department too there was no feverish anxiety to discover a solution to the crisis. One lone entry on the subject is to be found in the diary of Assistant Secretary Breckinridge Long, a close associate of Hull in the StateDepartment. Long did not mention any discussion in the Department concerning issues of policy posed by the fast, but he expressed his amusement at the predicament in which Ambassador Phillips found himself in New Delhi. "Phillips is having an unhappy few days at New Delhi ... crying for instructions", he wrote. The "natives" were pleading with Phillips and the newspapers were attacking him. "When pushed to ask Roosevelt to intervene Phillips replied he had cabled the President but had not heard!'1

On 20 February 1943 the President of the United States did make a move in regard to Gandhi's fast. A decision on this point must have been made some time during the previous three days. It is likely that it was made after the receipt at 4.49 p.m. on 19 February of Phillips' cable urging the President "to exert friendly pressure on the British Government through Lord Halifax" so that America's "record" would be strengthened.

Roosevelt did not take up the matter with Churchill or even, as suggested by Phillips, with Halifax. He instructed Hull to raise the issue with Halifax and to make clear his view that "Gandhi should not be allowed to die in prison".2

The British Ambassador had a surprise in store for him when he called on the Secretary of State on 20 February. Halifax had just begun to emphasize the inadvisability of any public statement by Phillips on Gandhi's fast when the Secretary abruptly cut him short. Gandhi's fast was the very subject on which the President had instructed him to talk with Halifax, Hull asserted. The President could not see why Phillips should remain quiet; indeed the President would go further and make clear his own views which was that Gandhi should not die in prison.

Hull went on to make explicit why the President had reached such a conclusion. In their own interest, the Secretary said, the British must

1 Diary entry, 16 February 1943, Box 5, Diary 22, Papers of Breckinridge Long, Library of Congress, Washington, DC, USA. "This is the first time Phillips has been in contentious territory and under attack - and he does not like it", Long added. There were no references to Gandhi's fast in the diaries of Admiral William Leahy (Library of Congress, Washington, DC), and of Secretary of War Henry L. Stimson (Manuscripts Division, Yale University Library, New Haven, Conn.).

2 Cordell Hull, The Memoirs of Cordell Hull (New York, 1948), II, p. 1492. 
consider "whether they can deal most effectively with Gandhi alive or with Gandhi dead and his supporters claiming martyrdom to a more or less [sic] degree."

Halifax did not engage in any argument with Hull and simply stated that he would communicate the President's message promptly to his Government. He, however, went on to reiterate his own request that Phillips should not make any public statement about Gandhi's fast since such a move would "give serious trouble". Having shot his bolt, Hull had resumed his usual cordial attitude and Halifax had little difficulty in winning the Secretary's concurrence for his request. ${ }^{1}$

Soon after the Ambassador's departure, Hull sent the following message to Phillips:

"... If you are still under heavy pressure from the press representatives I believe you might appropriately say that any phases of the Indian situation which require decision will be dealt with by ranking officials of the American and British Government."2

In India hopes of an American initiative were aroused when newspapers reported that Hull had met Halifax. There was excitement when Phillips told reporters that officials of the American and British Governments were discussing the Indian situation. A senior official of the State Department wrote to J. J. Singh, the President of the India League of America, that the United States Government had been following "all developments in the matter with close attention" and that an exchange of views had taken place between the Secretary of State and the British Ambassador "in regard to the different phases of the international situation including that of India". What all this actually amounted to was far from clear. Attempts by reporters to find out what exactly was involved in those discussions proved fruitless. The State Department announced that it could add nothing to Phillips' statement "than what appeared on the face of it". That was all that was necessary for the time being, Under Secretary Welles told reporters. Despatches in the New York Times, obviously based on authoritative briefings, made it clear that the Secretary's discussion with Halifax and Phillips statement in New Delhi did not signify any change whatsoever in the American policy of non-interference in Indian affairs. ${ }^{3}$

1 Memorandum of Conversation with the British Ambassador, by the Secretary of State, 20 February 1943, FR 1943, IV, pp. 199-200.

2 The Secretary of State to the Personal Representative of the President in India, 20 February 1943, ibid., p. 199.

3 Hindustan Times, 21 February 1943, p. 1; 22 February 1943, p. 1; 23 February 
In London the Prime Minister was confined to bed with a touch of pneumonia. The nature of his ailment was made public only on 24 February when he had nearly recovered. The strain of travels to Morocco and Turkey had taken its toll and Churchill had a week of "fever and discomfort" in the course of which he "sometimes felt very ill". His own predicament did not serve to soften his heart towards the ordeal of the man in Poona - the other "invalid", as he described Gandhi." On the other hand, Churchill was determined to persist in his "obduracy" towards Gandhi.

Secretary Hull's seemingly strong representation to Halifax and his unprecedented invocation of the President's name did not have the slightest impact on the Prime Minister. In blunt language he instructed his emissary in Washington to make it clear to Secretary Hull or any other interested American that the British Government would not, under any circumstances, alter the course that it was pursuing towards Gandhi.

Halifax took the Prime Minister's telegram to the State Department where, in the absence of Hull, he showed it to Welles. Churchill's message stated that any American intervention on the issue of Gandhi's fast would bring about great embarrassment between the Governments of the United States and Britain. Halifax could rest assured, it added,

1943, p. 1; 24 February 1943, p. 1; 26 February 1943, p. 2. New York Times, 21 February 1943; 24 February 1943, p. 9. The Hindu, 24 February 1943, p. 4. The Assistant Chief, Division of Near Eastern Affairs (Gordon P. Merriam), to Singh, n. d., February 1943, Singh Papers. At about this time Reuter reported from Washington that Secretary Hull had stated at a press conference that he could not understand the significance of the statement that Phillips had made. The report came as a "bombshell" to Phillips and he was distressed to see headlines in some newspapers to the effect that he had been repudiated by Hull. Phillips sent a telegram to Hull seeking clarification and received a reply a couple of days later to the effect that the Secretary had been misquoted and that Reuter's was being asked to correct their report. Diary entry, 23 February 1943, Indian Diary II, Phillips Papers. Reuter's misreporting on certain important occasions calls for deeper study. Even Dawn, organ of the Muslim League, demanded that there should be more accuracy in news cabled from abroad. "We cannot at the present time afford to have jumbled version from abroad of what is happening in India, certainly no sly suggestion that because of dissensions in India the Muslims are indifferent to the fate of Mahatma Gandhi whom they could with all good will love to see breaking his fast as a free man...", it wrote. Ed., "A Little More Truth", in: Dawn, 25 February 1943.

1 Winston S. Churchill, The Hinge of Fate (Boston, 1950), p. 736. According to his physician, Churchill took a "serious view of his illness" and "his mind was busy conjuring up possible complications." Lord Moran, Churchill (London, 1966), p. 88 . 
that London would show no weakness. And, as if to cut the State Department itself down to size, Churchill instructed the Ambassador to place the entire matter before Harry Hopkins, close friend and confident of the President. 1

The Prime Minister had no doubt that he could count on Hopkins to deal with the matter satisfactorily. He had formerly found Hopkins very co-operative on the Indian issue and there was no reason why the latter should not be equally understanding now. Even as he lay ill, Churchill kept the wires humming with personal messages to Hopkins. Hopkins was never allowed to forget that Churchill regarded him as his most intimate and loyal collaborator on the American side. At this very time Churchill was engaged in correspondence with the American on the supersecret "Tube Alloys" project - the code name for the atom bomb. ${ }^{2}$ Two symbols so diametrically opposed to each other - the ABomb and Mahatma Gandhi - had juxtaposed themselves on the attention of Britain's Prime Minister and the President's friend. The Gandhi issue was disposed of quickly.

No indication is available of what Hopkins actually did when Halifax communicated Churchill's telegram to him. With serene confidence the Prime Minister released to the press, on 22 February, his reply to the appeal that the Conference of Indian Leaders had addressed to him for the release of Gandhi. The reply was virtually the equivalent of a death warrant. "His Majesty's Government endorse the determination of the Government of India not to be deflected from their duty towards the people of India and of the United Nations by $\mathrm{Mr}$. Gandhi's attempt to secure his unconditional release by fasting", Churchill declared. Two days later he cabled Hopkins that he was feeling definitely better and "so is Gandhi". ${ }^{3}$

President Roosevelt had made his point "for the record", and he was not willing to go any farther. When Welles informed him of Churchill's

1 Churchill's telegram is summarized in Hull, Memoirs II, p. 1493.

2 Robert Sherwood, The White House Papers of Harry L. Hopkins (London, 1949), II, pp. 700-1. Sherwood draws attention to the significant fact that Churchill was, at that time, conducting discussions on "Tube Alloys" with Hopkins rather than with Roosevelt. Churchill also chose to send Hopkins on 27 February a long cable that gave a "complete record of all Anglo-American dealings since the first exchanges in 1940". The cable was to reinforce his demands in respect of a British role in "Tube Alloys". By chance or by design, at critical points in Indian affairs Churchill managed to place in the hands of Roosevelt and Hopkins documents extolling the partnership of the two countries and the appropriateness of a spirit of accommodation on the part of the United States towards what they portrayed as Britain's very legitimate aspirations.

3 Text of Churchill's reply in Leaders' Conference (quoted above, pp. 161f., n. 3), p. 49. Sherwood, op. cit., II, p. 700. 
telegram to Halifax, the President responded that "the United States Government would not say anything now". He added that if Gandhi were to die, he (Roosevelt) "would have some statement to make". The President also directed that in the event of Gandhi's death the Secretary of State should "make clear the fact that this Government had expressed its concern over the possibility of Gandhi's death and its belief that the difficulties in the Indian situation would be less grave if he were alive than if he were permitted to die."1

It is not clear whether any draft of a Presidential statement to be issued in the event of Gandhi's death was prepared. But in the State Department Hull lost no time in preparing for all emergencies. On 23 February a draft statement of the State Department was submitted to the War Department for approval on an urgent basis. Two days later the Secretary communicated to Phillips the text of a statement which, he stated, would be released by the Department "in the event Gandhi dies". "It is thought that foreknowledge of this statement may be helpful to you, and you will no doubt wish to see that it is likewise released in India if Gandhi's death occurs", Hull added. ${ }^{2}$

The statement sent by the Secretary was nothing more than a reiteration of the instructions to American forces in India issued on 12 August 1942. These were to the effect that American troops were in India purely for the defence of the country against the Japanese and that they were not to be involved in any internal developments. Up to this time those instructions had remained the only public expression by the Government of the United States relating to the political situation in India. If Gandhi died, America would speak again and reiterate the old statement. The objective was the same, to divert possible Indian indignation from the United States and to deter any attacks on American personnel, equipment, or supplies.

A reference to the fasting prisoner in Poona was made in the House of Representatives on 23 February 1943. A woman Representative from Illinois, Jessi Sumner, obtained the permission of the Speaker to make some brief comments. Said the Congresswoman:

"Mohandas Gandhi has millions of followers in India who regard him not as a human being but as a hallowed saint who can do no wrong. His well-advertised death in prison would be a powerful weapon our enemies would use unscrupulously. Neither we nor our allies can afford to waste lives and resources quelling revolts now.

1 Hull, Memoirs, II, p. 1493.

2 The Secretary of State to the Personal Representative of the President in India, 25 February 1943, FR 1943, IV, pp. 203-4. 
I, therefore, hereby beg on bended knee that Gandhi be released before he dies ..... I urge it be done as a gracious concession to soft-hearted Americans like me, of whom, I think there are plenty." 1

The members of the House heard her politely and then proceeded, without further ado, to debate a bill for the appointment of an additional Assistant Attorney General.

This was the only reference to Gandhi and, indeed, to the Indian political situation, in either chamber of the United States Congress during the whole of 1943.

\section{THE TIMING OF A "WHITE PAPER"}

On 21 February the doctors attending on Gandhi issued a bulletin to the effect that "if the fast is not ended without delay, it may be too late to save his life." The American envoy in New Delhi could not fail to take note of the intense anguish among all sections of the Indian people brought on by the announcement. Three Indian members of the Viceroy's Executive Council had tendered their resignations in view of their disagreement with the Viceroy over Gandhi's continued incarceration. Arriving for a banquet at the house of Sir J. P. Srivastava, one of the Indians who had stuck to his place in the Viceroy's Council, Phillips found that fifty guests had regretted their inability to attend in view of Gandhi's condition. The host's wife and two daughters were absent and the American envoy learned that they had boycotted the banquet in view of their concern over the Mahatma's life and their intense feeling against the Government. Returning to his official residence, Bahawalpur House, after lunch one afternoon, Phillips found several school girls seated on the floor waiting to appeal to him to do something to save the life of Gandhi. At the other end of the scale were several members of the Viceroy's Council who begged Phillips, in strict confidence, to make some move that might save the Mahatma. "To all such appeals", Phillips subsequently recalled, "I could only say that I was keeping the President fully informed of the situation. This I did daily by cable through the department, which was all I could do, for I had no instructions to proceed otherwise."2

1 Congressional Record, 89 (1943), p. 1212.

2 William Phillips, Ventures in Diplomacy (North Beverly, Mass., 1952), p. 360. Diary entry, 22 February 1943, India Diary II, Phillips Papers. The Viceroy and his close associate, Sir Gilbert Laithwaite, remained firm and unruffled. Ian Stephens, editor of the Statesman who was a guest at a party in Sir Gilbert's home on the most critical day recalled that the latter seemed "entirely calm" and "enjoyed his party as always". Ian Stephens, Monsoon Morning (London, 1966), p. 96 . 
Phillips conveyed to Roosevelt a picture of the extraordinary spectacle that he was witnessing in India and also his own role as a helpless onlooker. Wrote the envoy:

"It is difficult for Anglo-Saxons to understand the deep-seated feelings which have been aroused by this performance of an old man of 73 years .... That such a being is willing to sacrifice himself for the cause that every Indian has at heart, namely, the independence of India, has touched the people of India as a whole. While, of course, Gandhi's methods in the past are not approved, probably by the majority, nevertheless his honesty of purpose is respected and Indians who have been violently against him have now joined the chorus of appeals in his behalf. There could be nothing like it in any other country but India.

... But the Viceroy has remained adamant and has refused to listen to any appeals. He regards the case as one of defiance to law and order which must be dealt with accordingly. He does not feel, I fear, the pathos in the appeal of these millions for freedom for their own country. He is certainly a man of determination, for he has shown no weakening in his policy to let Gandhi bear the consequences of his fast and die in the process if necessary, no matter what the results may be. Perhaps he is a "chip of the old block" that Americans knew something about in 1772."

Phillips described to the President how he had been "literally besieged by callers and overwhelmed by telegrams from all parts of India, asking whether there could not be something done from Washington or by me to relieve the present deadlock." Indians, the envoy added, "turn to us to give them help because of our historic stand for liberty."1

The envoy made no reference in his letter to an action taken by the British Indian authorities on the previous day. That he ignored it was in itself a commentary on his evaluation of that action. On that day, when grave anxiety had been expressed by doctors over Gandhi's life, the Government of India released an official white paper entitled Congress Responsibility for the Disturbances. ${ }^{2}$ The document was a highly partisan attempt to pin the responsibility for the disturbances and sabotage that had taken place in various parts of India on the Congress and on Gandhi himself and to convey the impression, by innuendo and quotations out of context, that Gandhi's course was proJapanese. Such charges had been the staple of British propaganda

1 The Personal Representative of the President in India to the President, 23 February 1943, FR 1943, IV, pp. 201-3.

2 Congress Responsibility for the Disturbances (Delhi, 1942). 
since August 1942, and as such there was really nothing new in the white paper. The only new factor was the imminent prospect of Gandhi's death. The white paper, said the New Statesman and Nation, was "a propaganda document primarily designed ... to damage him [Gandhi] in American eyes". 1

The correspondent of the New York Times reported that the white paper would undoubtedly have "great importance for the historic record". On some future date the Congress Working Committee would have to issue its reply and then the world would judge, he added. ${ }^{2}$ Linlithgow himself had warned Gandhi earlier that sooner or later Gandhi and his colleagues would have to meet the charges against them and "clear yourselves before the world if you can". Gandhi had given his reply to the Viceroy's mocking admonition: "Posterity will judge between you as representative of an all-powerful Government and me as a humble man who has tried to serve his country and humanity through it." 3

Leaders of the American Government had made their own judgment. While they did not line up with Churchill and Linlithgow, neither did they make more than a perfunctory effort to avert a tragic end of Gandhi's fast. They were not influenced in any significant way by the reports of their own representative in Delhi who was a diplomat of great experience and a confirmed Anglophile. They wavered but for a moment in their adherence to the policy of silence and they proceeded with renewed faith in its importance and efficiency. Their loyalty and understanding during that trying period was acknowledged by Churchill in his war memoirs. "I kept the President fully informed throughout, and no pressure was put upon us from the United States", he wrote.

1 "Responsibilities in India", in: New Statesman and Nation (London), Vol. 25 (27 March 1943), p. 200. A Conservative weekly on the other hand, described the white paper as "factual evidence" which proved that Gandhi's policy had "all along been playing into the hands of the enemy". "What Gandhi Intended", in: Spectator (London), No 5987 (26 March 1943), pp. 281-2. In a letter to the Government of India on 15 July 1943 Gandhi took note of the fact that the introduction to the white paper by Tottenham was dated 13 February 1943, three days after the commencement of the fast. "The date is ominous. Why was the period of my fast chosen for publishing a document in which I am the target?", Gandhi asked. Was the white paper hurriedly released "in expectation of my death which medical opinion must have considered almost a certainty?" "It reads", Gandhi added, "like the presentation of a case by a prosecutor. In the present case the prosecutor happens to be also the policeman and jailor. He first arrests and gags his victims, and then opens the case behind their backs." Correspondence with Mr. Gandhi, p. 34.

a New York Times, 23 February 1943, p. 17.

3 Linlithgow to Gandhi, 5 February 1943; Gandhi to Linlithgow, 7 February 1943 ; Correspondence with Mr. Grandhi, pp. 9-11, 11-12.

- Churchill, The Hinge of Fate, p. 737. 
Mahatma Gandhi survived his fast. He had stated that he would fast for twenty one days and had expressed his fervent hope that he would survive. The end of his ordeal was welcomed with relief by millions in India.

As Phillips had reported to the Secretary of State and the President, the tight censorship imposed by the British prevented the American public from learning about the reaction of the Indian people to the fast. When the fast ended, American readers learned from editiorials in their newspapers that Gandhi had suffered a humiliating defeat. Some newspapers like the New York Times and periodicals like the Nation expressed the view that it might be appropriate for Britain to be magnanimous in victory and to make concessions to the Indians. ${ }^{1}$

Other American newspapers hastened to write Gandhi's political obituary. "Mr. Gandhi failed to die", sarcastically wrote the New York Herald Tribune. "And with that failure a great deal in the last thirty years of Indian history crashed in ruins to the grounds." The newspaper made it clear that even if Gandhi had passed away, it might not have viewed the event as specially tragic. The United Nations were so preoccupied with the war that they could not get excited over the death of one more man among the hundreds of thousands dying in the struggle. ${ }^{2}$

The Chicago Daily News was once again in a class by itself. Only a few American lunatics were agitated over Gandhi's fast, it asserted. Most people outside India recognized it as "phoney" and refused to get excited about it. Gandhi's technique was infantile - he was like the tot that held its breath until its face turned purple, or the unstable person who contemplated suicide muttering to himself that "they'll be sorry they treated me the way they did when I'm found dead." People everywhere realized that Gandhi was in no danger whatsoever, save a

${ }^{1}$ Despatch from Herbert Matthews, New York Times, 3 March 1943, p. 10; ed., "Gandhi Ends His Fast", ibid., 4 March 1943, p. 18. Nation, Vol. 156 (6 March 1943), p. 326. Current History (New York), Vol. 4 (April 1943), p. 123. Survey of press opinion, in Acting Secretary of State to the United States Mission in New Delhi, 5 March 1943, 845.00/1799, Files of the State Department.

2 Ed., "A Decisive Battle", in: New York Herald Tribune, 4 March 1943. The newspaper saw some good emerging out of Gandhi's "total failure". Indians would be forced to face facts as they witnessed the collapse of the "meretricious mysticism of the last two or three decades". The Tribune's correspondent in India, Sonia Tamara, reported that it was doubtful whether Gandhi would ever again stand at the head of the Congress, or even play any important part at all in Indian politics in the future. "India's Fire of Revolt Dies Down", ibid., 3 March 1943; “India's Problems Baffling As Ever”, ibid., 12 May 1943. 
type of danger that would come to any so-called Mahatma when he began to lose his following, the newspaper asserted. ${ }^{1}$

Gandhi's fast was "a propaganda flop", said Raymond Clapper, noted columnist of the New York World Telegram. Americans were not aroused by it and that was why they remained silent, he added. Clapper was of the view that, in general, Americans felt no sense of urgency concerning India as they did early in 1942. It looked then as though a Japanese attack on India was imminent and that Britain might agree to a settlement with the Indians. "Neither eventuality is possible now. So the Americans, if they think at all about the matter, are apt to file it quietly away ...."2

In the present discussion we have been concerned only with President Roosevelt's attitude towards an incident - a fast - in which one man in a distant land was involved. Millions in India regarded Gandhi as a great leader and a great soul. But Roosevelt and his advisers had little knowledge of the life and work of the man and the significance of what he stood for. India was to Roosevelt a theatre of war under the control of America's great ally, Britain. Preoccupied with the immense pressures and problems of the war, the Roosevelt Administration had little interest in getting embroiled with British leaders over Gandhi's fate.

American commentators like Raymond Clapper and even many Indian observers were unable to comprehend what Gandhi was able to accomplish in the face of tremendous odds. William Phillips came much closer to the mark in his analysis of the galvanizing effect that Gandhi's self-imposed ordeal had on his dis-spirited countrymen. Whether Gandhi consciously strove for such a result or not, the extraordinary outpouring of popular emotions that the fast evoked - cutting across regional, religious, and linguistic differences - can be seen, in retrospect, as yet another landmark in the slow and agonizing evolution of a consciousness of nationhood among India's millions.

Himself immured in prison, separated from his closest associates, and subjected to an unceasing campaign of vilification, Gandhi, by his fast, forced into the open the issue of the incompatibility between the proclamations of the Allied leaders and India's condition of involuntary servitude.

1 "Nursery Technic", in: Chicago Daily News, 4 March 1943. With scant respect for accuracy Churchill wrote in his memoirs that Gandhi "abandoned" his fast when he became "quite convinced of our obduracy". Churchill, op. cit., p. 737. 2 Quoted in Hindustan Times, 1 April 1943, p. 1. A note in Current History stated that India did not hold the centre of the stage in respect of the war and Gandhi's bargaining power was weak. "Gandhi's Moment of Trial", in: Current History, Vol. 4 (March 1943), pp. 40-41. 
In March 1943 Gandhi appeared to be a "failure" while the men of "blood and iron" who were directing the affairs of powerful nations appeared to be triumphant heroes. It is doubtful whether this appraisal can now be regarded as very accurate. Gandhi's life and message appear to have a continuing and contemporary relevance as man wrestles with the age-old problem of how to fight injustice and promote revolutionary change without the brutalizing employment of violence.

$\mathrm{Had}$ Gandhi died as a prisoner of the British, a wound would have been inflicted on the Indian heart that might have required long years to heal. Reconciliation with Britain might have proved immeasurably more difficult for India. Friendliness towards the United States might well have been supplanted by bitterness and resentment. ${ }^{1}$ But, fortunately, Gandhi lived - and the bitter memories of his ordeal disappeared from the national consciousness.

1 Time magazine reported that as the fast progressed, "Indian scorn included Americans as allies of the British, despite a faint hope that the U.S. might still intervene." Time (Chicago), Vol. 41 (1 March 1943), p. 20. 